\title{
STUDI ETIKA BISNIS BERDASARKAN ALKITAB
}

\author{
Philip Suciadi Chia'), Juanda ${ }^{2)}$ \\ ${ }^{1)}$ Southern Baptist Theological Seminary - Kentucky USA \\ E-mail: pchia275@students.sbts.edu \\ 2) Evangelical Theological Seminary of Indonesia - Surabaya \\ E-mail: juanda@sttii-surabaya.ac.id
}

\begin{abstract}
Business ethics is part of special ethics (applied), which initially developed in the United States, where it highlights various moral aspects of human behavior that have professions in business and management.

Studying business ethics can help people who are in the business world to be able to formulate and apply ethical principles in the economics and business world among each other. It is expected that ethical principles can help determining the right attitude in dealing with conflicts (both interests and conscience) that arise when doing business.

Of course, the Bible will be a foundation (reference) in formulating ethical principles in business. Thus, this paper limits business ethics that only based on biblical truth, so that it does not open a space for business ethics based on the secular world.

In addition, the writer will discuss the relationship between ethics and business, definition, various presuppositions in doing business, some examples of violations of business ethics and closed for the purpose of Bible-based business ethics.
\end{abstract}

Keyword: Business, Business Ethics, Bible

\begin{abstract}
Abstrak
Etika bisnis merupakan bagian dari etika khusus (terapan), yang pada awalnya berkembang di Amerika Serikat, di mana menyoroti pelbagai segi moral perilaku manusia yang mempunyai profesi di bidang bisnis dan manajemen.

Mempelajari etika bisnis dapat membantu mereka yang menggeluti dunia bisnis untuk dapat merumuskan serta menerapkan prinsip-prinsip etika dibidang ekonomi maupun dunia bisnis antar sesama. Prinsip-prinsip etika ini pun diharapkan dapat menolong dalam menentukan sikap yang benar dalam menghadapi konflik-konflik (baik kepentingan maupun hati nurani) yang timbul tatkala berbisnis.

Tentu saja Alkitab akan menjadi landasan (acuan) dalam merumuskan prinsipprinsip etika dalam berbisnis. Dengan demikian, tulisan ini membatasi etika bisnis hanya berdasarkan dari kebenaran Alkitab, sehingga tidak membuka ruang bagi etika bisnis menurut dunia sekuler.
\end{abstract}


Di samping itu, penulis akan membahas mengenai kaitan antara etika dengan bisnis, definisi, berbagai presuposisi dalam berbisnis, beberapa contoh pelanggaran akan etika bisnis dan ditutup dengan tujuan etika bisnis yang berdasarkan Alkitab.

Kata Kunci: Bisnis, Etika Bisnis, Alkitab

\section{INTRODUKSI}

Banyak pengusaha berkeberatan dengan penerapan standar etika dalam aktivitas bisnis. Bagian ini membahas keberatan-keberatan tersebut serta evaluasi terhadapnya.

Pada umumnya, mereka menganggap bahwa seseorang yang terlibat di dalam bisnis terfokus pada pencarian ataupun keuntungan finansial semata sehingga tidak perlu untuk membuang-buang waktu ataupun sumber daya perusahaan untuk melakukan "pekerjaan baik".:

Ada tiga keberatan diajukan atas penerapan etika ke dalam bisnis:

Pertama. Mereka berpendapat bahwa di pasar bebas yang bersifat kompetitif, masing-masing perusahaan dengan sendirinya akan terfokus pada kegiatan memproduksi barang-barang yang diinginkan oleh anggota masyarakat dengan cara yang paling efisien dan efektif. Perusahaan dan banyak pihak akan diuntungkan apabila manajer tidak memaksakan nilai-nilai etika pada bisnis, namun mengabdikan dirinya usaha bisnis tersebut. ${ }^{1}$

Argumentasi ini menyembunyikan sejumlah asumsi yaitu karena sebagian besar industri tidak "kompetitif secara sempurna".

Maksudnya ialah banyak perusahaan, terutama perusahan yang baru atau masih kecil, yang tidak mungkin terus menerus berkompetisi. Di samping itu, perusahaan lebih banyak kompetisi bukanlah tujuan tetapi meningkatkan keuntungan (mengejar target laba perusahaan) itulah yang menjadi tujuan akhir perusahaan. Dengan kata lain, kompetisi dalam pasar bebas hanyalah salah satu wadah untuk meningkatkan laba perusahaan.

Oleh karena itu, keberatan tersebut hanya merupakan dalih yang sebenarnya hanya terfokus pada keuntungan (hasil) semata. Di lain pihak, keberatan ini akan menghasilkan pelbagai tindakan untuk menghalalkan segala cara demi meraup keuntungan sebanyak mungkin (menjadi tamak) seperti menyembunyikan cacat produksi, melakukan penyuapan dan menghindari pajak.

Kedua. Keberatan berikut ini dikembangkan oleh Michales dengan topik "argumentasi dari agen yang loyal". Argumentasi tersebut secara sederhana ialah sebagai agen yang loyal mempunyai kewajiban untuk melayani customer ketika ingin dilayani dengan cara apapun untuk kepentingannya.

${ }^{1} \underline{\text { Ketut Rindjin, Etika Bisnis dan }}$

Implementasinya (Jakarta: Gramedia, 2004), 78. 
Dengan pola pikir seperti inilah timbul penyataan bahwa "customer adalah raja“. ${ }^{2}$

Argumentasi dari agen yang loyal adalah keliru karena tidak dapat membedakan antara profesionalitas dalam bekerja dengan menjadi budak bagi pekerjaan. Menjadi profesional dalam bekerja berarti tidak mengorbankan nilai-nilai intergritas maupun harkat ataupun derajat tetapi tetap bertanggung jawab dengan segala pekerjaannya. Budak pekerjaan ialah menganggap pekerjan sebagai tuhan di mana manusia harus mempertaruhkan derajat, prinsip-prinsip hakiki (agama maupun sosial) bahkan kesuciannya sendiri. Pekerjaan hanyalah suatu sarana bukan suatu tujuan dari kehidupan.

Ketiga. Keberatan yang terakhir mengatakan bahwa etika bisnis pada dasarnya adalah mentaati hukum. Evaluasi dari keberatan ini ialah pada kenyataannya bisnis sering sekali memberlakukan konsep tujuan menghalalkan segala cara. Bahkan tindakan yang berbau kriminal pun ditempuh demi pencapaian suatu tujuan. Kalau sudah demikian, pengusaha yang menjadi pengerak motor perekonomian akan berubah menjadi binatang ekonomi. ${ }^{3}$ Hal ini mengakibatkan meningkatkan perbuatan tercela dalam dunia bisnis di negara hukum. Etika berbeda dengan hukum.

\footnotetext{
${ }^{2}$ http://www.dailybust.com/pdf-files/$\frac{\text { lingkungan-etika-dalam-lingkungan-e-bisnis. }}{3}$.

http://ejournal.unud.ac.id/abstrak/\%2812\%29\%2 0soca-anderson-etika\%20bisnis\%281\%29.pdf
}

Etika berbicara mengenai pengaturan hakikat perilaku manusia yang baik dan buruk secara universal. Hukum berbicara mengenai perilaku yang wajib atau larang untuk dilakukan dalam suatu negara. Dengan demikian, etika lebih berbicara pada hakikat atau esensi dari perilaku dan bersifat lebih internal berbeda dengan hukum yang eksternal. Tindakan tidak mengindahkan kepentingan masyarakat, tidak memperhatikan sumber daya alam maupun tindakan KKN dan suap merupakan segelintir contoh "pengabdian" para pengusaha dalam berbisnis berkenaan dengan hukum.

Dalam masyarakat tanpa etika, seperti ditulis oleh filsuf Hobbes, ketidakpercayaan dan kepentingan diri yang tidak terbatas akan menciptakan "perang antar manusia terhadap manusia lain”, dan dalam situasi seperti itu hidup akan menjadi "kotor, brutal, dan dangkal". Karenanya dalam masyarakat seperti itu, tidak mungkin dapat melakukan aktivitas bisnis karena akan hancur. Dengan demikian, etika dibutuhkan untuk mempertahankan kelangsung bisnis. Bisnis merupakan aktivitas kooperatif yang eksistensinya mensyaratkan perilaku etis. ${ }^{4}$

Di samping itu, beberapa studi menunjukan hubungan yang positif antara perilaku yang bertanggung jawab secara sosial dengan profitabilitas. Perusahaan yang bertanggung jawab

${ }^{4}$ Harun Hadiwijono, Sari Sejarah Filsafat Barat 2. (Yogyakarta: Kanisius, 1983.. 32-35. 
secara sosial bertransaksi di pasar saham, memperoleh pengembalian yang lebih tinggi daripada perusahaan lainnya. Semua studi menunjukan bahwa secara keseluruhan etika tidak memperkecil keuntungan, dan tampak justru berkontribusi pada keuntungan.Hal ini dikarenakan meningkatkan

hubungan koperatif dengan pelanggan, karyawan dan anggota masyarakat dimana kesuksesan bisnis sangat bergantung. ${ }^{5}$ Dengan demikian, ada sejumlah argumentasi kuat yang mendukung pandangan bahwa etika hendaknya diterapkan dalam bisnis.

Definisi.

Secara sederhana yang dimaksud dengan etika bisnis adalah cara-cara untuk melakukan kegiatan bisnis, yang mencakup seluruh aspek yang berkaitan dengan individu, perusahaan, industri dan juga masyarakat. ${ }^{6}$ Akan tetapi, definisi tersebut masih bias (kurang jelas) karena hanya mengungkapkan sesuatu yang deskriptif tetapi tidak menyentuh hingga kepada sesuatu yang normatif.

Dengan demikian, etika bisnis yang baik harus berbicara hal yang normatif terlebih dahulu baru masuk kepada bagian deskriptif. Oleh karena itu, etika bisnis merupakan suatu kode etik dari perilaku pengusaha yang

\section{${ }^{5}$ Ketut Rindjin, Etika Bisnis dan} Implementasinya, 106.

6 Purba Victor, Hukum Bisnis Dalam Kegiatan Bisnis Para Manajer Manajemen, (Dunia Bisnis Warta Ekonomi, No. 29, diperoleh dari pelbagai nilai maupun moral (dari Alkitab) untuk menjadi tuntunan dalam membuat keputusan dalam berbisinis. Inilah normatif. Pengusaha Kristiani tidak dapat bergantung pada norma etika dunia untuk mengetahui cara dalam menjalankan usahanya. Mereka memerlukan suatu dasar kepercayaan yang lebih pasti untuk tindakannya. Dasar ini dapat ditemukan dalam Alkitab, hati nurani dan bimbingan Allah yang khusus dalam hidup seseorang. Dengan demikian, etika menurut Allah ialah kepatuhan terhadap yang Alkitab katakan. ${ }^{7}$ Setelah kajian normatif ditemukan maka kajian deskriptif dalam ditentukan yang mencakup berbagai macam kegiatan dalam berbisnis seperti bertransaksi.

\section{PRESUPOSISI DAN EVALUASI DALAM BERBISNIS}

Von der Embse dan R.A. Wagley dalam artikelnya di Advance Management Journal (1988), memberikan beberapa pandangan dasar dalam merumuskan tingkah laku etika bisnis, yaitu ${ }^{8}$ :

- Utilitarian Approach : Setiap tindakan harus didasarkan pada konsekuensinya. Oleh karena itu, dalam bertindak seseorang

Desember 1994).

${ }^{7}$ Jerry White, Kejujuran, Moral dan Hati Nurani (Jakarta, BPK Gunung Mulia, 1999), 59.

${ }^{8}$ Von der Embse dan R.A. Wagley, Advance Management Journal (1988). 
seharusnya mengikuti cara-cara yang dapat memberi manfaat sebesar-besarnya kepada rekan bisnis, dengan cara yang tidak membahayakan dan dengan biaya serendah-rendahnya.

- Individual Rights Approach : Setiap orang dalam tindakan dan kelakuannya memiliki hak dasar yang harus dihormati. Namun tindakan ataupun tingkah laku tersebut harus dihindari apabila diperkirakan akan menyebabkan terjadi benturan dengan hak orang lain.

- Justice Approach : Para pembuat keputusan mempunyai kedudukan yang sama, dan bertindak adil dalam memberikan pelayanan kepada pelanggan baik secara perseorangan ataupun secara kelompok.

Berikut ini merupakan evaluasi dari ketiga pandangan tersebut:

a. Utilitarian tidak dapat menjawab konflik yang bisa timbul antara memberi manfaat kepada masyarakat sebesar-besarnya dengan kemungkinan biaya yang tinggi. Sering kali, harus diakui, baiknya kualitas barang disertai dengan kenaikan harga barang tersebut. Tidak hanya itu, apabila konflik ini muncul maka pengusaha yang menganut presuposisi ini akan lebih mengutamakan dirinya sendiri daripada masyarakat karena terfokus pada konsekuensi yang akan diterimanya. Lebih baik mengorbankan orang lain daripada diri sendiri. b. Individual Rights memiliki kesan untuk menghindar daripada persoalan di dalam bisnis sehingga pandangan ini mengatakan bahwa bila terjadi konflik antara hak antara penjual dengan pembeli harus dihindari. Konflik antara penjual maupun pembeli harus diselesaikan meskipun terkadang dengan jalan mengorbankan salah satu hak baik di penjual ataupun pembeli.

c. Justice Aprroach jauh lebih baik di antara kedua pandangan sebelumnya karena berbicara tentang cara pandang pengusaha yang memandang semua rekan bisnis maupun pembeli memiliki kedudukan yang sama dan bertindak adil (tidak pilih kasih) baik terhadap siapapun juga. Kesemuanya ini mencakup caracara menjalankan bisnis secara adil, sesuai dengan hukum yang berlaku, dan tidak tergantung pada kedudukan individu ataupun perusahaan di masyarakat. Kendati demikian, adapula konflik-konflik moral yang terkadang tidak dapat dielakkan sehingga sulit untuk dapat berlaku adil.

Norman L. Geisler menambah satu presuposisi yang penting dalam beretika yaitu

deontologis. Kata ini berasal dari Yunani yang terdiri dari kata deon (kewajiban) 
Jurnal Teologi \& Pelayanan ( Kerusso )

E-ISSN: 2714-9587

P-ISSN: 2407-554X

dan $\log o s$ (ajaran). ${ }^{9}$ Etika ini lebih mengutamakan prinsip (dari Alkitab) daripada hasil atau dengan kata lain hasil tidak menentukan prinsip pengusaha untuk melangkah. Para pengusaha melangkah karena ingin memberikan pelayanan yang baik kepada konsumen (kewajibannya) lebih daripada melihat hasilnya.

Hasil bukan segalanya tetapi prinsip-prinsip dari Alkitab itulah merupakan dasar dari segalanya (bdkgn. Mat. 25:20-26). Di samping itu, prinsipprinsip ini tidak dapat berubah karena berasal dari wahyu Allah yang mutlak dan absolut. Beberapa pakar dalam etika bisnis mengatakan bahwa hati nurani yang menjadi dasar utama dalam etika bisnis. ${ }^{10}$ Akan tetapi, hati nurani manusia tidak dapat menjadi dasar etika karena sudah tercemar oleh dosa (Rm 13). Oleh karena itu, manusia membutuhkan Alkitab yang akan menjadi tolak ukur dan terang bagi hati nurani dalam berbisnis.

Di samping deontologis, Geisler juga menyarankan absolutisme bertingkat sebagai solusi bila ada konflik-konflik yang tidak dapat terelakkan. Prinsip ini mengatakan ada banyak prinsip-prinsip moral yang berakar di dalam karakter moral Allah yang mutlak namun ada kewajibankewajiban moral yang lebih tinggi. ${ }^{11}$ Sebagai contohnya ialah kasih kepada Allah merupakan satu kewajiban yang

\footnotetext{
${ }^{9}$ Norman L. Geisler, Etika Kristen (Malang, SAAT: 2001), 26.

${ }^{10}$ N.Nuryesrnan M, Moral dan Etika

Dalam Dunia Bisnis Bank dan Manajemen, Mei/Juni 1996.
}

lebih besar daripada kasih kepada manusia.

Bila terjadi konflik di dalam bisnis (berbenturan hak), lebih baik bagi seorang pengusaha rugi secara finansial dalam satu waktu untuk memberikan haknya kepada klien yang sudah lama berbisnis dengan baik. Hal ini disebabkan di dalam bisnis yang terpenting bukanlah hak atau uang tetapi kepercayaan dari klien. Oleh karena itu, etika bisnis berperan dalam memberikan kepercayaan terhadap individu maupun kelompok.

\section{PELANGGARAN ETIKA BISNIS TERHADAP KONSUMEN}

\section{Sebuah perusahaan property}

ternama di Yogjakarta tidak memberikan surat ijin

membangun rumah dari developer kepada dua orang konsumennya di kawasan kavling

perumahan milik perusahaan tersebut. Kedua konsumen ini sudah memenuhi kewajibannya membayar harga tanah sesuai kesepakatan dan biaya administrasi lainnya. Akan tetapi, setiap kali dipertanyakan kepada pihak developer selalu berdalih dengan alasan belum mendapatkan ijin dari pusat

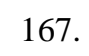


perusahaan (pusatnya di Jakarta).

Hal yang ganjil ialah di antara kawasan kavling itu hanya dua orang ini yang belum mengantongi izin pembangunan rumah, sementara 30 konsumen lainnya sudah diberi izin dan rumah mereka sudah dibangun semuannya. Alasan yang dikemukakan perusahaan ini kepada orang lain ialah pemberian pelajaran kepada dua konsumen tadi karena dua orang ini karena telah memprovokasi konsumen lainnya untuk melakukan penuntutan segera pemberian izin pembangunan rumah. Dari kasus ini perusahaan property tersebut telah melanggar prinsip kewajaran (fairness) karena tidak memenuhi hak-hak konsumen dengan alasan yang tidak masuk akal. ${ }^{12}$

Bagi orang-orang yang mengeluti bisnis lebih terfokus kepada perolehan daripada sikap yang memberi. Perlu diingat bahwa kekayaan itu sendiri bukanlah sesuatu yang buruk. Hal yang buruk ialah kekayaan dijadikan berhala. ${ }^{13}$ Cinta yang berlebihan pada kekayaan merupakan satu dari dosa yang mendatang kejahatan dan mengakibatkan dosa lain (1 Tim. 6:6-10; Ibr. 13:5) yang dapat mengorbankan orang lain.

Dalam bisnis, konsep melayani manusia harus menjadi dasar bagi semua yang kita lakukan. Pelayanan merupakan kata kunci dalam semua jenis bisnis. Orang yang berbisnis perlu untuk mencoba memenuhi kebutuhan-

12

http://ejournal.unud.ac.id/abstrak/\%2812\%29\%2 0soca-anderson-etika\%20bisnis\%281\%29.pdf kebutuhan orang lain yaitu bertindak bagi kepentingan terbaik konsumennya. Jika pengusaha-pengusaha menempatkan pelayanan konsumen sebagai hal-hal pertama maka mereka bertindak seperti yang Tuhan firmankan. Kolose 3:23 menyatakan bahwa apapun yang juga kamu perbuat, perbuatlah dengan segenap hatimu seperti untuk Tuhan dan bukan untuk manusia. Efesus 6:6-7 menyatakan bahwa jangan hanya di hadapan mereka saja untuk menyenangkan hati orang, tetapi sebagai hamba-hamba Kristus yang dengan segenap hati melakukan kehendak Allah dan yang dengan rela menjalankan pelayanannya seperti orang-orang yang melayani Tuhan dan bukan manusia.

Alkitab, secara khusus PL, memandang kekayaan sebagai perwujudan kebaikan ilahi. Allha menghadiahkan kekayaan bagi mereka yang dikasihi-Nya: Abraham (Kej. 24:34-35), Ishak (Kej. 26:12-14), Salomo (1 Raj. 3:11-13), Hizkia (2 Taw. 32:27-39). Mengenai tindakan esktrem dari bahwa untuk memuaskan konsumen dapat dilakukan dengan menghalalkan segala cara dan mengorbankan semua nilai-nilai yang hakiki telah dibahas di dalam bagian agen yang loyal.

\section{PELANGGARAN ETIKA BISNIS TERHADAP SESAMA PENGUSAHA}

\author{
${ }^{13}$ Karl Heinz Peschke, Etika Kristiani \\ IV (Maumere: Ledalero, 2003), 256.
}


Sebuah perusahaan pengembang di Sleman membuat kesepakatan dengan sebuah

perusahaan kontraktor untuk membangun sebuah perumahan. Sesuai dengan kesepakatan

pihak pengembang memberikan spesifikasi bangunan kepada kontraktor. Namun dalam

pelaksanaannya, perusahaan kontraktor melakukan penurunan kualitas spesifikasi

bangunan tanpa sepengetahuan perusahaan pengembang. Selang beberapa bulan kondisi

bangunan sudah mengalami kerusakan serius. Dalam kasus ini pihak perusahaan

kontraktor dapat dikatakan telah melanggar prinsip kejujuran karena tidak memenuhi

spesifikasi bangunan yang telah disepakati bersama dengan perusahaan pengembang. ${ }^{14}$

Kejujuran menuntut pengusaha Kristiani untuk berbisnis sesuai dengan kesepakatan yang telah ditentukan dan harus bertanggung jawab atas kualitas hasil produksinya sesuai dengan harga yang patut. Kejujuran juga meliputi pemenuhan syarat-syarat perjanjian atau kontrak, mutu barang atau jasa yang ditawarkan, dan hubungan kerja yang benar di dalam berbisnis. Dengan menyatakan bahwa hasil produksi yang

14

http://ejournal.unud.ac.id/abstrak/\%2812\%29\%2 0soca-anderson-etika\%20bisnis\%281\%29.pdf berkualitas rendah sama dengan

berkualitas tinggi adalah tindakan yang tidak jujur. Para pengusaha Kristiani harus bersedia mengambil resiko untuk menjadi rugi dalam usaha-usaha bisnis mereka untuk mempertahankan prinsipprinsip Alkitab yang benar. Alkitab dengan jelas mengatakan bahwa ketidakjujuran dan penipuan merupakan kejahatan di hadapan Tuhan, "Janganlah kamu berbuat curang dalam peradilan, mengenai ukuran, timbangan dan sukatan" (Im. 19:35, U1. 19:14; 25:1316; Ams. 11:1). Siapa yang merugikan sesamanya karena kelemahannya harus membayar ganti rugi seluruhnya. Dan siapa yang didapati melakukan pencurian atau penipuan, mesti menggantikan barang yang diperoleh secara tidak adil itu dua kali atau lebih (Kel. 21:37-22:14; Bil. 5:6-7). Oleh karena itu, nama baik yang disebabkan oleh kejujuran jauh lebih penting daripada iklan-iklan ataupun promosipromosi. ${ }^{15}$ Kejujuran terhadap langganan berarti cara baik dalam melakukan bisnis. ${ }^{16}$ Prinsip ini paling problematik karena masih banyak pelaku bisnis melakukan penipuan.

\section{PELANGGARAN ETIKA BISNIS TERHADAP NEGARA}

Sebuah perusahaan $\mathrm{X}$ di kawasan Green Ville mengembangkan akan usaha mesin percetakan. Pada akhir tahun 2010, petugas pemerintah pajak datang

$I V, 60 .{ }^{15}$ Karl Hei 
untuk memeriksa modal (baik berupa uang maupun benda-benda yang tak bergerak) maupun laporan keuangan untuk kepentingan SPT PPh Badan (1771) sesuai dengan yang dipersyaratkan oleh UU No. 28/2007 Pasal 28 (7) di mana sekurangkurangnya terdiri atas catatan mengenai harta, kewajiban, modal [neraca], penghasilan, biaya [laporan laba-rugi] serta penjualan dan pembelian, sehingga dapat dihitung besarnya pajak yang terutang. ${ }^{17}$ Akan tetapi perusahaan $\mathrm{X}$ tersebut mengurangi segala modal usaha dan memanipulasi neraca keuangan mereka untuk mendapatkan beban pajak yang lebih sedikit.

Tindakan ini dapat dikategorikan sebagai penipuan karena memanipulasi jumlah barang maupun mengadakan permainan pajak melalui neraca keuangan. ${ }^{18}$ Dengan demikian, tindakan ini melanggar hukum dan juga merugikan negara. Alkitab mencatat bahwa Kejujuran ini bukan hanya kepada konsumen tetapi juga pada pemerintah yaitu dengan membayar pajak sebagai ketaatan kepada pemerintah (Rom. 13:1, 3, 6-7). Di samping itu, Yesus pun juga menyetujui akan membayar pajak kepada kaisar (pemerintah) tatkala menghadapi akan pertanyaan dari orang-orang Farisi maupun Herodian (Mark. 12:13-17). Dengan demikian, etika bisnis yang baik ialah tidak mengabaikan pajak sebagai hak negara dan kewajiban pengusaha

\footnotetext{
${ }^{17} \mathrm{http} / / /$ www.pajak.go.id/

18 Tuntutan untuk mendapat ganti rugi dari asuransi dengan memberikan data yang tidak benar atas fakta yang ada.
}

untuk membayarkannya.

\section{TUJUAN ETIKA BISNIS}

Etika bisnis dalam perusahaan memiliki peran yang sangat penting, yaitu untuk membentuk suatu perusahaan yang kokoh dan memiliki daya saing yang tinggi serta mempunyai kemampuan menciptakan nilai (valuecreation) yang tinggi, diperlukan suatu landasan yang kokoh. Dengan menghargai konsumen, maka bisnis dapat menjadi alat agar membantu kebutuhan manusia. ${ }^{19}$ Tujuan akhir manusia ialah kemuliaan dan pujian kepada Allah sehingga bisnis pun harus diabdikan pada tujuan ini. Tujuan bendabenda ciptaan bukanlah agar mereka dikumpulkan sebanyak-banyaknya tetapi sebagai sarana untuk melayani Allah dan manusia. Hal ini dapat menyebabkan terjalinnya relasi serta kepercayaan yang kuat antara penjual dengan konsumen. Di samping itu, nama baik dikalangan para konsumen merupakan modal yang sangat penting bahkan sangat membantu pengusaha untuk berkompetisi di dalam dunia usaha.

Bagi sesama rekan pengusaha, etika bisnis berguna untuk meningkatkan efisiensi dan kualitas. Harus dipahami bahwa kompetisi bisnis seharusnya tersebut tidak menghalalkan segala cara untuk meraup keuntungan tetapi dalam

\footnotetext{
${ }^{19}$ K. Bertens \& Sonny Keraf Kanisius, Pengantar Etika Bisnis (Yogyakarta: Kanisius 2000), 201.
} 
berkompetisi secara sehat. Maksudnya ialah dengan memiliki etika bisnis yang Alkitabiah dapat mendorong para pengusaha untuk lebih bertanggung jawab terhadap kualitas (produk maupun pelayanan) sekaligus memicu semangat bekerja perusahaan untuk menghasilkan yang terbaik bagi konsumen. Di samping itu, kompetisi bukan berarti harus menghancurkan perusahaan lainnya. Tetapi bisa menjalin kerjasama seperti pengadaan training di perusahaan yang lebih unggul sehingga dapat memberikan spread effect terhadap perkembangan sekitarnya. $^{20}$

Berkenaan dengan pemerintah sehingga banyak para pengusaha yang sering menggelapkan pajak ataupun menyogok para staff pemerintah bagian perpajakan. Dengan adanya etika bisnis dapat membantu para pengusaha untuk belajar meningkatkan suatu perencanaan strategis, pengorganisasian yang baik, mengembangkan sistem prosedur yang transparan didukung oleh budaya perusahaan yang handal serta etika perusahaan yang dilaksanakan secara konsisten dan konsekuen daripada bertindak curang tentang pajak. Perusahaan harus siap untuk transparan sehingga bisa melihat dan memperbaiki akan ketidak-efektifan di dalam perusahaan tersebut. Hal ini bisa berupa menekan akan biaya-biaya pengeluaran yang tidak terlalu diperlukan seperti pemakaian inventaris kantor untuk keperluan pribadi melalui telepon interlokal dan sebagainya. Barangbarang di kantor adalah milik kantor dan persoalan pribadi dengan kantor harus dapat dibedakan secara baik serta jelas. Hal ini dapat memacu tanggung jawab yang baik dari pekerja di perusahaan dan

${ }^{20}$ K. Bertens \& Sonny Keraf Kanisius, Pengantar Etika Bisnis, 157. juga menciptakan suasana kondusif bagi perusahaan sebagai milik bersama-sama. Di samping itu, sistem prosedur yang transparan terhadap neraca keuangan perusahaan beserta dengan pajaknya akan membentuk serta memberikan teladan mental maupun karater yang baik terhadap perusahaan tersebut.

Dengan demikian, etika bisnis bertujuan untuk mengembangkan tanggung jawab pengusaha yang meliputi tanggung jawab terhadap dirinya sendiri, rekan bisnis, konsumen, pemerintah, dan masyarakat.

\section{KESIMPULAN}

Para pengusaha banyak yang melakukan tindakan penipuan di dalam bisnisnya. Bila hal ini dianalisa maka jawabannya ialah terletak pada ketamakan manusia. Ketamakan ini disebut di dalam Alkitab yaitu akar segala kejahatan (1 Tim. 6:10).

Ketamakan tidak menaruh hormat kepada Allah maupun sesama. Ketamakan dapat mendorong manusia untuk melangkahi batas-batas perintah Allah dan merampas milik orang lain dengan jalan-jalan yang tidak halal. ${ }^{21}$

Oleh karena itu, etika bisnis yang benar ialah didasarkan pada Alkitab saja dengan pendekatan deontologis yang berfokus bukan pada tujuan tetapi pada prinsip-prinsip Alkitabiah yang ditekankan. Etika bisnis yang Alkitabiah bertujuan untuk mengajak para pelaku bisnis dalam mewujudkan citra dan manajemen bisnis yang baik (etis) agar bisnis itu pantas dimasuki oleh semua

${ }^{21}$ J. Verkuyl, Etika Kristen II (Jakarta, BPK Gunung Mulia, 1985), 177. 
orang yang mempercayai adanya dimensi etis dalam dunia bisnis. Hal ini sekaligus menghalau citra buruk dunia bisnis sebagai kegiatan yang kotor, licik, dan tipu muslihat dan membantu pengusaha untuk mencari cara guna mencegah tindakan yang dinilai tidak etis. Etika bisnis ini pun diharapkan dapat meningkatkan keadilan sosial, penghargaan terhadap hak milik orang lain dan persaingan yang sehat dalam berbisnis.

\section{KEPUSTAKAAN}

[1] Bertens, K. \& Sonny Keraf Kanisius, Pengantar Etika Bisnis. Yogyakarta: Kanisius 2000.

[2] Chia PS, Juanda J. Understanding The Relationship Between Faith and Knowledge. Journal DIDASKALIA. 2020 Apr 8;3(1):1-6.

[3] Embse, Von der dan R.A. Wagley. Advance Management Journal. 1988.

[4] Geisler, Norman L. Etika Kristen. Malang, SAAT: 2001.

[5] Hadiwijono, Harun. Sari Sejarah Filsafat Barat 2. Yogyakarta: Kanisius, 1983.

[6] Rindjin, Ketut. Etika Bisnis dan Implementasinya. Jakarta: Gramedia, 2004.

[7] Http://www.dailybust.com/pdf-files/lingkungan-etika-dalam-lingkungan-ebisnis.
[8]

http://ejournal.unud.ac.id/abstrak/\%2812 $\% 29 \% 20$ soca-andersonetika\%20bisnis\%281\%29.pdf

[9] Http://www.pajak.go.id/

[10] N. Nuryesrnan M, Moral dan Etika Dalam Dunia Bisnis Bank dan Manajemen, Mei/Juni 1996.

[11] Peschke, Karl Heinz. Etika Kristiani IV. Maumere: Ledalero, 2003.

[12] Victor, Purba. Hukum Bisnis Dalam Kegiatan Bisnis Para Manajer Manajemen, Dunia Bisnis Warta Ekonomi, No. 29, Desember 1994.

[13] White, Jerry. Kejujuran, Moral dan Hati Nurani. Jakarta, BPK Gunung Mulia, 1999 
Jurnal Teologi \& Pelayanan ( Kerusso )

E-ISSN: 2714-9587

P-ISSN: 2407-554X 